\title{
CHROMITE MACROCRYSTS IN KIMBERLITES AND LAMPROITES: GEOCHEMISTRY AND ORIGIN.
}

\author{
W.L. Griffin ${ }^{(1)}$; C.G. Ryan ${ }^{(1)}$; J.J. Gumey ${ }^{(2)}$; N.V. Sobolev ${ }^{(3)}$ and T.T. Win ${ }^{(1)}$.
}

(1) CSIRO Div. of Exploration Geoscience, Box 136, N. Ryde 2113, Australia; (2) Dept. of Geochemistry, Univ. Of Cape Town, Rondebosch 7700, Sout Africa; (3) Inst. of Geology \& Geophysics, USSR Academy of Sciences, Novosibirsk, USSR.

Introduction: Macrocrysts of chrome-spinel (CMs; 0.2-2mm, anhedral to euhedral) are common in many kimberlites and lamproites, and are important as indicator minerals during diamond exploration. However, the use of chromites in exploration is usually based on major-element criteria which may be ambiguous. Analysis of trace elements by proton microprobe can add another level of discrimination, and a program to this effect is in progress at the CSIRO. Here we discuss major- and trace-element data on $>1000$ chromites from kimberlites and lamproites worldwide, on $>170$ diamond-inclusion (DI) chromites from South Africa and Siberia, and on $>70$ garnet-chromite pairs from xenoliths and concentrates. Data for various elements are combined in Figure 1.

Data: CMs from kimberlites show limited ranges in $\mathrm{Cr} 2 \mathrm{O} 3$ (45-65\%) and $\mathrm{Al} 2 \mathrm{O} 3$ (2\%$12 \%$; $\mathrm{Cr} \#[\mathrm{Cr} /(\mathrm{Cr}+\mathrm{Al})]$ ranges from 0.7 to 0.95 . Lamproite $\mathrm{CMs}$ show a much greater range to lower $\mathrm{Cr}$ and higher $\mathrm{Al}$, with $\mathrm{Cr} \#$ down to 0.2 ; there is little overlap in $\mathrm{Al} 2 \mathrm{O} 3$ between kimberlite and lamproite $\mathrm{CM}$ populations. $\mathrm{Mg \#}[\mathrm{Mg} /(\mathrm{Mg}+\mathrm{Fe})]$ ranges mainly from 0.4 to 0.7. CMs from Group 2 kimberlites extend to lower $\mathrm{Mg} \#$ than those from Group 1 kimberlites, and lamproites contain significant numbers of high-Mg\#, low-Cr\# spinels. In general there is no correlation between $\mathrm{Mg} \#$ and $\mathrm{Cr} \#$; the low-Cr "tail" in Fig. 1 is defined by a small proportion $(<10 \%)$ of the sample.

More than $1 / 3$ of the analyzed CMs contain $>1 \%$ TiO2, and many, especially in Group 2 kimberlites, contain $2-4 \%$. Ti typically shows a broad negative correlation with $\mathrm{Al}$ and $\mathrm{Mg \#}$, and a weak positive correlation with $\mathrm{Cr}$, expecially in lamproites. In general, therefore, chromite macrocrysts from kimberlites and lamproites follow the first part of Mitchell's (1987) "Trend 2", rather than the "AMC trend". Ni contents of CMs range from 300-2000 ppm; they show no correlation with $\mathrm{Mg \#}$ or $\mathrm{MgO}$, but are broadly anticorrelated with $\mathrm{Cr}$. The highest Ni values are found in the low-Cr CM populations in lamproites. Group 2 kimberlites contain two major populations of CMs with Ni contents of ca. 400-700 ppm and 900-1200 ppm, respectively; Group 1 kimberlites have one major population with ca. $600-900 \mathrm{ppm}$. Zn contents of CMs in kimberlites are mainly in the range $400-900 \mathrm{ppm}$, with a few higher values. Lamproites, and some Siberian kimberlites, contain many CMs with $\mathrm{Zn}>1000$ ppm; the high-Ni population in lamproites contains 200-500 ppm $\mathrm{Zn}$ and shows a negative correlation between $\mathrm{Zn}$ and Ni. Ga contents of CMs range from $<2-100$ ppm, and show a broad positive correlation with $\mathrm{Ni}$.

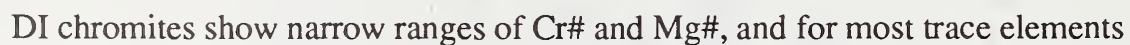
as well. Siberian DI chromites show significantly lower Mg\# and $\mathrm{MgO}$, and higher $\mathrm{Zn}$, than those from South Africa. Ti and Ga contents of DI chromites are typically low, but even lower values of $\mathrm{Ga}$ are found in $\mathrm{CMs}$ from kimberlites.

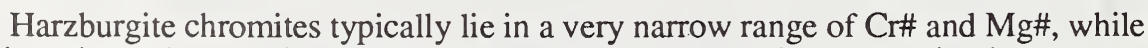
lherzolite spinels show a wider range of $\mathrm{Cr} \#$ and a rough negative correlation between $\mathrm{Cr} \#$ and Mg\#. Only four xenolith spinels, all from lherzolites, contain $>1000 \mathrm{ppm} \mathrm{Ni}$. $10 \%$ of the analyzed xenolith spinels, divided equally between harzburgites and lherzolites, contain $>1 \% \mathrm{TiO} 2$. In general, lherzolite spinels contain less $\mathrm{Ni}$, more $\mathrm{Ga}$ and more $\mathrm{Zn}$ than harzburgite spinels. The Nickel Thermometer (Griffin et al., 1989) allows calculation of a temperature for each garnet-chromite pair. Fig. 2 shows a good correlation between $1 / \mathrm{T}$ and the $\mathrm{Zn}$ content of the xenolith spinels, and probably reflects partitioning between chromite and olivine. The correlation between $\mathrm{Ni}$ and $1 / \mathrm{T}$ is not as good, which suggests bulk-composition effects on the partitioning of $\mathrm{Ni}$.

\section{Discussion:}

(1) Origin of macrocryst chromites: Comparison of the CM populations with the data on xenolith spinels provides clues to the origin of chromite macrocrysts. The low-Ti 
CMs in Group 1 kimberlites appear to be true xenocrysts, derived mainly from harzburgites. Very low-Ga CMs from these kimberlites may be derived from as garnetfree chromite harzburgites and dunites. Group 2 kimberlites contain two major populations, one of which is equivalent to the xenolith spinels. The minimum $\mathrm{Zn}$ content of this population is higher than the equivalent in Group 1 kimberlites, indicating a lower maximum temperature. The other population in Group 2 kimberlites is essentially identical to Mitchell's (1987) "Trend 2", and is considered to be magmatic (phenocrystal) in origin. CM concentrates from some Group 2 kimberlites are dominated by this magmatic population. CMs intermediate between the two major populations in Group 2 kimberlites may reflect reaction of xenocryst spinels with (proto-?)kimberlite magma; this may also be the origin of high-Ti CMs in Group 1 kimberlites. CM concentrates from lamproites typically contain relatively few xenocrystal spinels, and many of these are low- $\mathrm{T}$ lherzolite chromites. The major CM population in many lamproites has high $\mathrm{Ti}, \mathrm{Ni}, \mathrm{Cr}$ and lower $\mathrm{Mg \#}$. It also follows Trend 2, but at higher $\mathrm{Mg \# ,} \mathrm{MgO}$ and $\mathrm{Ni}$, and lower $\mathrm{Zn}$, than the corresponding population in Group 2 kimberlites. It is interpreted as a magmatic population, reflecting a higher temperature of crystallization.

(2) Mantle stratigraphy and origin of host rocks: The general separation of the xenolith spinels with harzburgites at high $\mathrm{T}$ and lherzolites at lower T (Fig. 2) might reflect a general stratification of the cratonic lithosphere. Alternatively, it may reflect a general lack of spinel-bearing lherzolites at greater depth. The distribution of $\mathrm{T}_{\mathrm{Ni}}$ in garnet concentrates from kimberlites strongly suggests that lherzolites and harzburgites are interleaved in the deeper parts of the lithosphere, and that lherzolites are volumetrically dominant.

The $\mathrm{Mg}$ and $\mathrm{Zn}$ distributions in their respective xenocryst populations suggest that Group 1 kimberlites have sampled the mantle from greater depths, on average, than Group 2 kimberlites. This is consistent with derivation of Group 1 kimberlites from the asthenosphere and Group 2 mainly from the lithosphere. Sr-Nd data suggest that both Group 2 kimberlites and lamproites are derived from enriched lithosphere; the differences in their magmatic CM populations suggest that the major difference between the two rock types is the higher temperature of lamproitic magmas.

(3) Implications for Exploration: The use of "diamond inclusion" compositions to evaluate exploration targets may be misleading, since $\mathrm{MgO}$ contents, in particular, will be affected by cooling following diamond formation. Also, many high-grade Group 2 kimberlites are dominated by the magmatic $\mathrm{CM}$ population, which should be recognized as a positive indication although it has lower $\mathrm{Mg \#}$ and $\mathrm{Cr} \#$ than DI chromites. The low-P limit of the diamond stability field corresponds to ca. $950^{\circ} \mathrm{C}$ on a cratonic geotherm; reference to Fig. 2 shows that only chromites with <ca. $700 \mathrm{ppm} \mathrm{Zn}$, and >ca. $600 \mathrm{ppm}$ $\mathrm{Ni}$, are likely to be derived from the diamond stability field. The $\mathrm{Ga}$ content of chromites appears to correlate broadly with degree of depletion; DI spinels and harzburgite spinels typically contain $<30 \mathrm{ppm} \mathrm{Ga}$. The proportion of chromites with low $\mathrm{Zn}$ and $\mathrm{Ga}$, and high $\mathrm{Ni}$, in a concentrate may serve as a rough guide to the diamond potential of an exploration target.

Griffin, W.L., Cousens, D.R., Ryan, C.G., Sie, S.H. and Suter, G.F. 1989. Contrib. Mineral. Petrol. 103, 199-202.

Mitchell, R.H. 1987. Kimberlites: Mineralogy, Geochemistry and Petrology. Plenum Press, New York, 442 pp.

\section{FIGURES (next page)}

Fig. 1 a-e. Interelement relations in chromite macrocrysts from Group 1 and 2 kimberlites (Southern Africa) and lamproites (Australia, China, USA), compared with data from diamond-inclusion chromites and chromite-garnet peridotites.

Fig. 2 (lower right). $\mathrm{Zn}$ and $\mathrm{Ni}$ contents of chromites, plotted against $1 / \mathrm{T}$ as determined by nickel thermometry on coexisting chrome-pyrope garnets. 

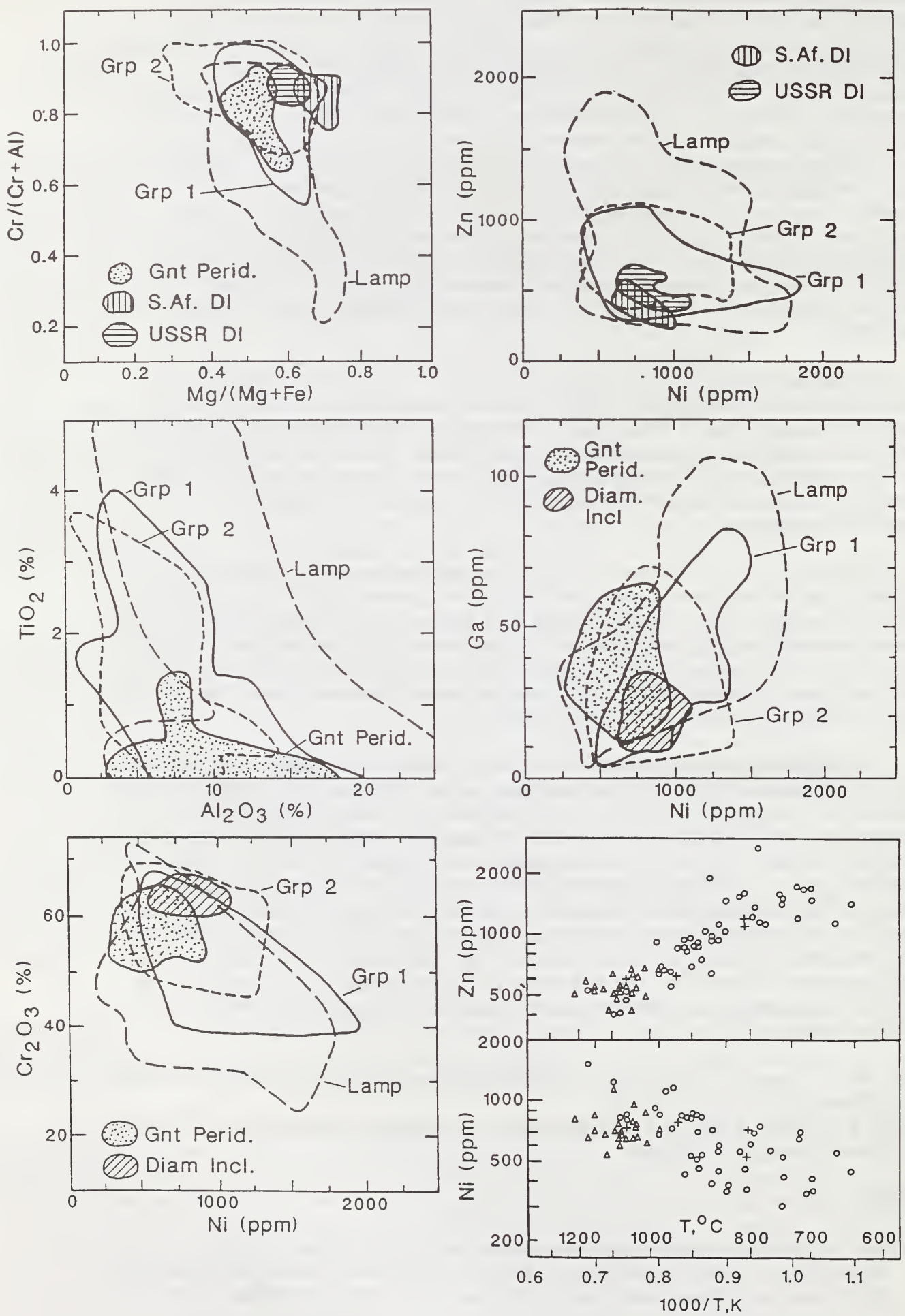